\title{
Long-term monitoring of the recruitment and dynamics of large wood in Kamienica Stream, Polish Carpathians
}

\author{
Paweł MIKUŚ * iD https://orcid.org/oooo-0oo3-1281-6229; e-mail: mikus@iop.krakow.pl \\ Bartłomiej WYŻGA iD https://orcid.org/oooo-0oo2-9923-2148; e-mail: wyzga@iop.krakow.pl \\ ${ }^{*}$ Corresponding author
}

Institute of Nature Conservation, Polish Academy of Sciences, al. Mickiewicza 33, 31-12o Kraków, Poland

Citation: Mikuś P, Wyżga B (2020) Long-term monitoring of the recruitment and dynamics of large wood in Kamienica Stream, Polish Carpathians. Journal of Mountain Science 17(6). https://doi.org/10.1007/s11629-019-5954-1

(C) The Author(s) 2020.

\begin{abstract}
Studies presenting long-term observations of the recruitment and mobility of large wood in mountain watercourses are scarce, but they can considerably contribute to the knowledge of river/riparian forest interactions and the assessment of flood hazard resulting from wood mobility during floods. Widespread dieback of riparian forest along the headwater course of Kamienica Stream in the Polish Carpathians, caused by bark beetle infestation of spruce trees, has raised concerns about potential increases of large wood recruitment to the stream and of the flood hazard to downstream valley reaches. In October 2009, 429 trees growing along three sections of the stream were tagged with numbered metal plates and monitored over 10 years to determine the timing and causes of their delivery to the channel and the lengths of their displacement during individual flood events. Moreover, in 2012 the mode of location of wood deposits and a degree of wood decay were determined in the second- to fourth-order stream reaches. The monitoring of tagged trees indicated that trees were recruited to the channel during highintensity meteorological and hydrological events, mostly as a result of bank erosion during floods or windthrow. With $22 \%$ of tagged trees recruited to the channel during 10 years, the rate of turnover of the riparian trees was estimated at 45 years. As the riparian area is overgrown with trees with ages up to $\sim 160$ years, the rate evidences substantial
\end{abstract}

Received: $20-$ Dec-2019

Revised: 04-Mar-2020

Accepted: 14-May-2020 intensification of large wood recruitment to the channel in the recent period. Results of large wood inventory and the 10-year-long monitoring of tagged trees indicated variable mobility of large wood along the upper course of the stream. Wood mobility was negligible in the second-order stream reach, very small in the third-order reach, and greater, but still limited in the fourth-order reach. Wood is transported longer distances only during major floods. However, the advanced state of decay of most pieces leads to their disintegration during floods, precluding distant transport. Thus, large wood retained in the upper stream course does not constitute an important flood hazard to downstream, inhabited valley reaches.

Keywords: Large wood; Wood dynamics; Wood monitoring; Wood inventory; Wood recruitment; Polish Carpathians

\section{Introduction}

Fallen trees and their fragments are an important component of fluvial environment, and their presence in river channels has been recorded in scientific literature since the 1830s (Lyell 1837). They are commonly known as large wood, which is generally defined as wood pieces with a length $>1$ $\mathrm{m}$ and a diameter $>0.1 \mathrm{~m}$. The presence of instream wood promotes biodiversity and decreases flow energy, but can also generate flood hazard 
because of the ability of wood to accumulate at bridges, culverts and weirs. Logs spanning a channel influence fluvial processes by forming dams and steps that facilitate dissipation of flow energy, reduce sediment transport and increase channel stability (Gurnell et al. 2002). Such channel forms may be very stable, depending on wood dimensions and hydrological regime. As large wood plays also a beneficial role for aquatic organisms and sustaining their habitats, reintroduction of wood in channels is one of the methods of stream restoration (Kail et al. 2007). Recent studies also documented significant geomorphic functions of wood pieces smaller than the standard large wood (with a length $\geq 0.5 \mathrm{~m}$ and a diameter $\geq 0.1 \mathrm{~m}$, or a length $\geq 1 \mathrm{~m}$ and a diameter $\geq 0.05 \mathrm{~m}$ ), that can be very abundant in Carpathian headwater streams (Galia et al. 2018a).

Large wood can be recruited to channels as a result of a range of factors (Keller and Swanson 1979; Ruiz-Villanueva et al. 2014) depending on the nature of the riverside area. These include episodic events such as bank erosion, strong wind, snow overload, snow avalanches, ice storms or forest fire (Benda and Sias 2003). Chronic tree mortality caused by insect activity considerably increases the effects of the above processes. Hillslopes can also be a potential area of wood delivery by mass movement processes, such as landslides and debris flows that typically occur at the same time as floods (Ruiz-Villanueva et al. 2014). Finally, forestry practices such as harvesting of trees and storing cut logs on channel banks may contribute to the delivery of wood to channels in case of bank erosion (Krejči and Máčka 2012). Among these recruitment mechanisms, relatively little is known about the effects of mass tree mortality caused by either tree diseases or catastrophic windstorms (Wohl 2017). In-channel wood can be entrained as a result of increasing discharge and transported downstream. However, its mobility depends on the ratio of log diameter to flow depth, conditioning wood flotation, and the ratio of log length to channel width determining the ability of logs to anchor on the channel banks (Montgomery et al. 2003). This mobility is thus low in headwater streams, which convey small flood discharges and have relatively narrow channels (Gurnell et al. 2002).

Wohl (2017) indicated that most large wood studies record wood loads existing and recruitment mechanisms operating in a brief moment in time. Quantifying wood delivery and mobility in small mountain streams requires long-term and repeatable observations, so far very scarcely described (Lienkaemper and Swanson 1987; Faustini and Jones 2003; Wohl and Goode 2008). In the last years a number of new methods were developed, such as video-monitoring (MacVicar and Piégay 2012), time-lapse photography (Kramer and Wohl 2014), aerial imagery with LiDAR (Queiros et al. 2018), tracking with radio transmitters (Wyżga et al. 2017) and even analysing data available on the Internet (RuizVillanueva et al. 2018). Not only can the monitoring of wood supply and mobility improve the scientific knowledge of these processes, but it also can be a practical tool for the assessment of flood hazard generated by floated wood for urbanized downstream reaches of the stream valley (Mikuś et al. 2016). Recently, observations using a number of remote sensing methods have gained popularity. However, classical methods of fieldwork still seem to be indispensable in more detailed studies. Such observations have been conducted in the upper course of Kamienica Stream, Polish Western Carpathians, where a relatively deep mountain valley and a thick canopy of riparian trees significantly limit the use of modern technology. This part of the stream course is located in a national park and large wood is left in the stream under the national park regulations. However, in the late 2000s a bark beetle infestation began in the valley, progressively infecting spruce stands in the riparian area and on the valley slopes over a few next years. This infestation has resulted there in a widespread dieback of riparian forest and a question arises as to whether the increased delivery of fallen trees to the channel can considerably augment flood hazard to downstream, inhabited reaches of the valley.

This study aims: (i) to determine the rates and the main factors of wood recruitment to the investigated mountain stream, (ii) to determine the dynamics of large wood in the stream based on the long-term monitoring of tagged trees and the inventory of in-channel wood, and (iii) to infer about the flood hazard to downstream reaches caused by the large wood retained in the stream segment within the national park. 


\section{Field setting}

Kamienica Stream originates in the Outer Western Carpathians, with the highest peak in its catchment (Turbacz) at $1311 \mathrm{~m}$ a.s.l. (Figure 1a). The stream drains an area of $128 \mathrm{~km}^{2}$ and ends its 34-km-long course flowing into the Dunajec River. The studied stream segment starts $0.4 \mathrm{~km}$ from the stream source at an elevation of $1195 \mathrm{~m}$ a.s.l. and ends $9.1 \mathrm{~km}$ from the source at $782 \mathrm{~m}$ a.s.l. (Figure $1 \mathrm{~b}$ ). The segment encompasses second-order and third-

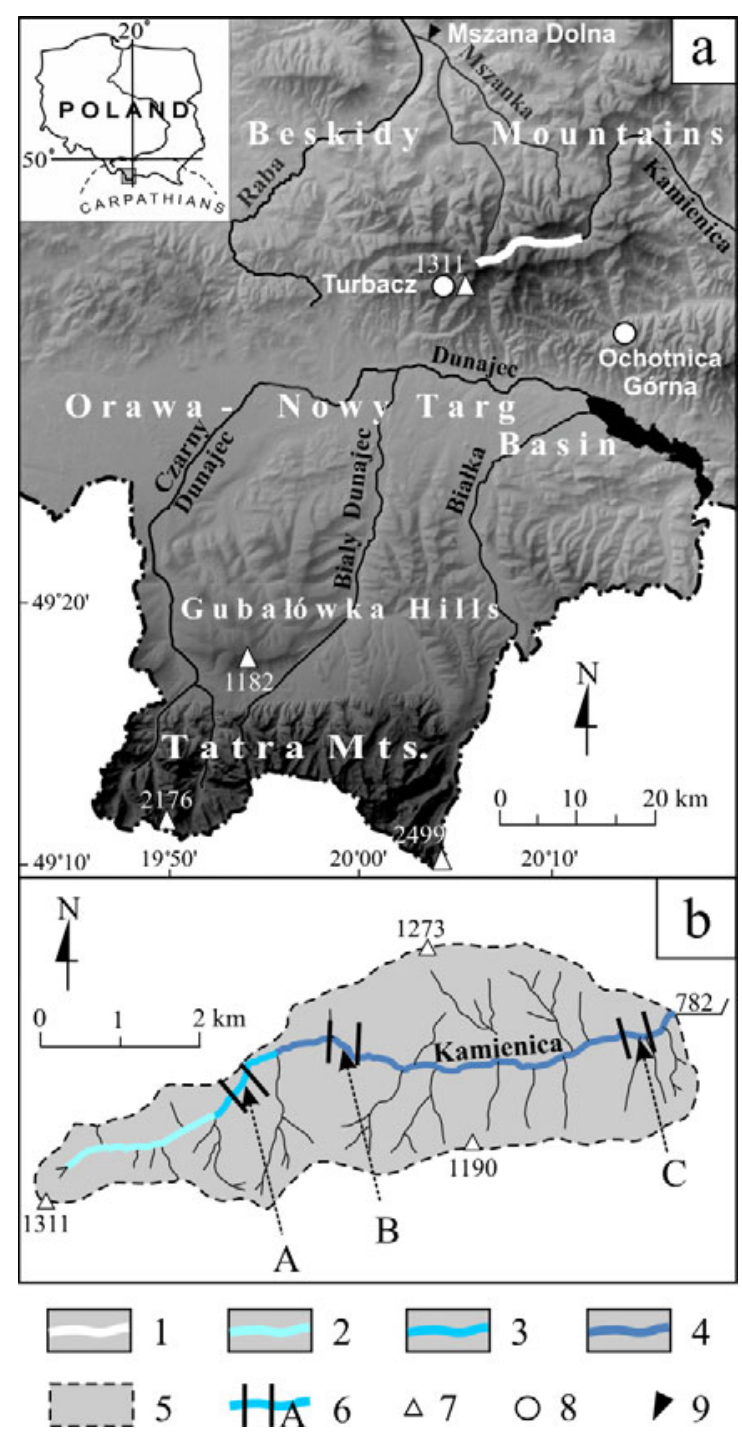

Figure 1 (a) Location of Kamienica Stream in relation to physiogeographic regions of southern Poland. (b) Drainage network of upper Kamienica and detailed setting of research. 1 - study segment of the stream; 2 second-order reach; 3 - third-order reach; 4 - fourthorder reach; 5 - boundary of Kamienica catchment; 6 stream sections with tagged trees; 7 - mountain summits; 8 - precipitation stations; 9 - water-gauge station. order channel reaches located at a distance of 0.4$2.3 \mathrm{~km}$ and $2.3-3.65 \mathrm{~km}$ from the stream source, respectively, and a part of a fourth-order reach between 3.65 and $9.1 \mathrm{~km}$ from the source (Figures 1b, 2, Table 1). The segment ends at the boundary of a strict nature reserve in the national park. The catchment area increases from $0.1 \mathrm{~km}^{2}$ at the beginning of the study segment of the stream to $14.9 \mathrm{~km}^{2}$ at its end (Figure $1 \mathrm{~b}$ ). A part of the stream course between 4.9 and $6.7 \mathrm{~km}$ from the source was excluded from observations because of difficult access (Figure 2), but it exhibits similar characteristics as the adjacent parts of the fourthorder stream reach.

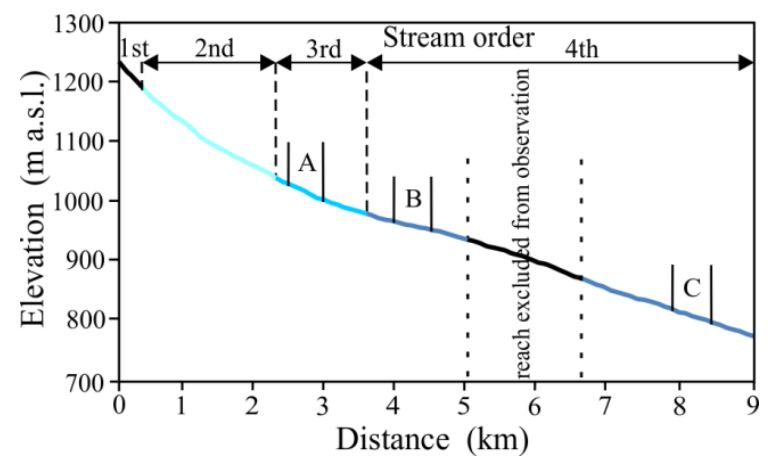

Figure 2 Location of the second-, third-, and fourthorder stream reaches with wood inventory performed in 2012, and of stream sections (A, B and C) with conducted monitoring of tagged trees shown on the longitudinal profile of the study segment of Kamienica Stream.

Channel slope decreases from $0.13 \mathrm{~m} \mathrm{~m}^{-1}$ in the uppermost part of the study segment to 0.035 $\mathrm{m} \mathrm{m}^{-1}$ in its lowest part (Figure 2). Mean channel slope in the second-, third- and fourth-order stream reaches equals $0.086,0.036$ and $0.055 \mathrm{~m}$ $\mathrm{m}^{-1}$ (Table 1). Because of considerable variation in catchment altitude, annual precipitation ranges from $800 \mathrm{~mm}$ near the stream mouth to the Dunajec River to more than $1200 \mathrm{~mm}$ in the highest parts of the catchment (Niedźwiedź and Obrębska-Starklowa 1991). Most precipitation falls between May and September. The coarse-grained (boulder to pebble) nature of the bed material in the study segment conditions its entrainment by flood flows of relatively high magnitudes; consequently, changes in the morphological pattern of the stream channel occur during floods caused either by a few days-long, moderateintensity rainfall with the total sum of precipitation of a few hundred millimetres or by high-intensity, short-lasting convective rain (Wyżga et al. 2016). 
Table 1 Morphometric characteristics of the study units of Kamienica Stream and number of tagged trees in sections A-C

\begin{tabular}{|l|l|l|l|l|l|l|} 
Study unit & $\begin{array}{l}\text { Length } \\
(\mathrm{m})\end{array}$ & $\begin{array}{l}\text { Distance from the } \\
\text { stream source }(\mathrm{km})\end{array}$ & $\begin{array}{l}\text { Elevation range } \\
(\mathrm{m} \text { a.s.1.) }\end{array}$ & $\begin{array}{l}\text { Mean channel } \\
\text { width }(\mathrm{m})\end{array}$ & $\begin{array}{l}\text { Mean channel } \\
\text { slope }\left(\mathrm{m} \mathrm{m}^{-1}\right)\end{array}$ & $\begin{array}{l}\text { Number of } \\
\text { tagged trees }\end{array}$ \\
\hline Second-order reach & 1900 & $0.40-2.30$ & $1195-1031$ & 5.80 & 0.086 & \\
\hline Third-order reach & 1350 & $2.30-3.65$ & $1031-983$ & 7.70 & 0.036 & \\
\hline Fourth-order reach & 3650 & $3.65-9.10$ & $983-782$ & 11.00 & 0.055 & \\
\hline Section A & 450 & $2.50-2.95$ & $1010-993$ & 8.30 & 0.038 & 148 \\
Section B & 450 & $4.00-4.45$ & $957-948$ & 9.70 & 0.020 & 140 \\
\hline Section C & 450 & $7.85-8.30$ & $809-794$ & 13.20 & 0.033 & 141
\end{tabular}

The stream banks are overgrown with subalpine forest dominated by spruce (Picea abies) in the upper part of the study segment and by spruce, beech (Fagus sylvatica) and fir (Abies alba) in its lower part. The height of riparian trees varies between 17 and $31 \mathrm{~m}$, with the average of $24 \mathrm{~m}$ (Wyżga et al. 2015). According to the classification of stream size by Gurnell et al. (2002), Kamienica is a stream of small width in its second-order reach, and of medium width in the third- and fourthorder reaches.

Since 1980, this area has been almost free of direct human impact due to the establishment of the Gorce Mountains National Park. This fact enabled us to study the recruitment and mobility of large wood under relatively natural conditions. In recent years, bark beetle (Ips typographus) infestation caused extensive dieback of spruce trees in the riparian forest and greatly increased the delivery of wood to the stream channel.

In the upper part of the study segment (second-order reach), the stream has a step-pool channel pattern with numerous bedrock steps and wood dams. Farther downstream (third- and fourth-order reaches), it has a riffle-and-pool pattern in the parts of the valley with flat-bottomed morphology and a step-pool pattern in V-shaped parts of the valley. The valley slopes are underlain by flysch rocks that are susceptible to fluvial erosion and mass movements. Since spring 2010 a middle part of the study segment with the flatbottom morphology and the most gentle channel slope (Figure 2, Table 1) has been inhabited by European beaver, Castor fiber, that seems to exert a significant impact on the riparian forest.

\section{Methods}

\subsection{Stream study units}

The study was carried out in two types of longitudinal stream units. The degree of decay and the location of large wood were investigated in autumn 2012 in the entire study segment of Kamienica and results of this survey were compared between the second-, third- and fourthorder stream reaches (Figures 1b, 2). A 10-yearlong monitoring of the recruitment of tagged riparian trees to the stream was conducted in three stream sections $450 \mathrm{~m}$ in length, with section $\mathrm{A}$ located within the third-order reach and sections $\mathrm{B}$ and $\mathrm{C}$ within the fourth-order reach (Figures $1 \mathrm{~b}, 2$ ).

\subsection{Monitoring of the recruitment and mobility of tagged riparian trees}

A methodology for investigating the rates of supply and mobility of large wood should be adjusted to stream size and expected distance of wood transport. In the case of Kamienica Stream with average channel width $<10 \mathrm{~m}$, searching for displaced wood did not require the use of sophisticated methods. In October 2009, numbered metal plates were installed on 429 trees growing along three stream sections within the national park (Figures 1b, 2). Principal morphometric characteristics of these sections are presented in Table 1. Different metals were used in each section: aluminium in section A located between $2500-2950 \mathrm{~m}$ from the stream source, copper in section B (4000-4450 m) and steel in section $\mathrm{C}(7850-8300 \mathrm{~m})$. This was intended to allow for finding tagged trees with a metal detector in case the plates on them are inaccessible and for identification of the section from which found trees derive in case of their long-distance displacement. Each tagged tree was healthy and had at least 10 $\mathrm{cm}$ diameter at breast height. Their position was recorded with a Trimble GeoXT GPS receiver with $0.5 \mathrm{~m}$ precision. We tagged trees growing closest to the channel on the floodplain or the valley sidetheir distance from the channel margin ranged 
from $\mathrm{o}$ to $12 \mathrm{~m}$. In section $\mathrm{B}$, the tagged sample consisted almost exclusively of spruce (98\%) with accessory proportions of goat willow (Salix caprea) and sycamore (Acer pseudoplatanus). In the uppermost section A, the species composition of the tagged sample was dominated by spruce (86\%) with the admixtures of beech, fir and sycamore. In the lowest section $\mathrm{C}$, spruce composed the majority of the sample (59\%) with secondary proportions of beech (27\%) and fir (10\%) and accessory proportion of sycamore (Table 2). We did not tagged trees growing along the first- and secondorder stream reaches because small stream discharges result there in low probability of transporting trees fallen to the channel (Gurnell et al. 2002).

The monitoring of standing and fallen trees tagged with metal plates has been conducted a few times per year, especially after heavy rainfall and windstorms. Time, location and recognized cause of tree delivery to the stream as well as the length of its displacement have been recorded. As Kamienica Stream has no water-gauge station, information about possible occurrence of high water stages has been obtained from traces of high flow apparent on stream banks during monitoring and records at gauging stations on nearby streams. Particularly useful were records of the Mszana Dolna water-gauge station on Mszanka Stream that drains a catchment adjacent to that of Kamienica Stream (Figure 1a). However, as this station characterizes the catchment with an area of 166 $\mathrm{km}^{2}-11$ times larger than that of Kamienica Stream at the end of the study segment-these records could only provide information about a relative scale of flood waves on Kamienica. In order to determine the amount of precipitation during heavy rainstorms, averaged data from the Turbacz and Ochotnica Górna precipitation stations (Figure 1a) were used.

\subsection{Inventory of the location and the degree of decay of large wood in the study segment}

In autumn 2012 an inventory of large wood in the $8.7-\mathrm{km}$-long study segment of Kamienica Stream (Figures $1 b, 2$ ) was carried out. Results of this inventory concerning the longitudinal distribution of wood in the study segment were described by Wyżga et al. (2015), and Mikuś et al.
(2016) compared orientation of wood pieces between the second- and the fourth-order stream reaches. The present study considers those characteristics of wood deposits, which are particularly informative about wood dynamics, i.e. the mode of location in the stream and the degree of wood decay. During the inventory, each wood deposit (individual piece or log jam) was assigned to one of six modes of wood location in the stream: (i) resting on channel margin, (ii) on channel bar, or (iii) in low-flow channel, (iv) with tree top or bottom in the channel, (v) forming partial, complete or active dam, and (vi) spanning the channel. A degree of decay of all wood pieces stored in the study reach was classified into one of the four categories ( 1 - fresh, bark adheres tightly; 2 - loose bark; 3 - no bark, wood hard; 4 - no bark, wood soft) defined by Lienkaemper and Swanson (1987).

\section{Results}

\subsection{General pattern of the delivery and displacement of tagged trees}

During ten years of observations, 96 trees (22.4\% of the tagged sample) were supplied to the stream as a result of bank erosion, windthrow of living trees or those killed by bark beetle infestation, snow overload and landslides (Figure 3). In October 2009, at the very beginning of the observation period, $80 \mathrm{~cm}$ of wet snow fell in two days and snow overload caused breaking of two tagged trees. Five events with high water stage occurred in May 2010, May 2014, July 2016, July 2018 and May 2019 (Table 3). The rainfall causing these floods was typified by considerable spatial variation, which hindered drawing firm conclusions about the relative scale of these events on the basis of precipitation and discharge data from the nearby rain- and water-gauge stations (Table 3). However, as the floods from 2016 and 2018 caused significant channel changes and damage to the infrastructure in the Kamienica valley, both in the national park and outside its boundary, they can be considered as major floods on the stream. The relatively small size of Kamienica Stream facilitated searching for trees displaced by floods. However, about half of trees 
Table 2 Species composition of the riparian trees tagged with metal plates in study section A (upper), B (middle) and C (lower)

\begin{tabular}{|l|l|l|l|}
\hline Species & Section A & Section B & Section C \\
\hline Picea abies & $78.4 \%$ & $98.6 \%$ & $59.6 \%$ \\
\hline Fagus sylvatica & $14.8 \%$ & - & $27.0 \%$ \\
\hline Abies alba & $1.4 \%$ & $0.7 \%$ & $9.9 \%$ \\
\hline Acer pseudoplatanus & $5.4 \%$ & - & $3.5 \%$ \\
Salix caprea & - & $0.7 \%$ & -
\end{tabular}

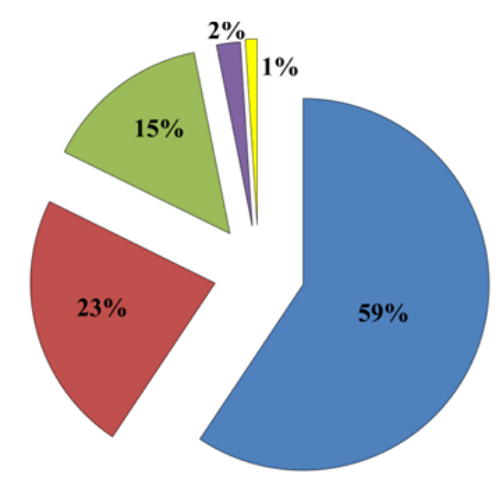

$\square$

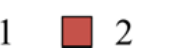

3

4

\section{5}

Figure 3 Percentage of tagged trees recruited to Kamienica Stream between 2009 and 2019 as a result of: (1) bank erosion, (2) windthrow of living trees, (3) tree dieback followed by windthrow, (4) overloading with snow, (5) landslide.

supplied to the channel were not transported, and numerous wood dams occurring in the stream limited transport of any fallen trees. Out of 96 supplied trees, 46 (48\%) were transported during some of these five floods and of this number, only 5 trees were displaced during two events. The range and mean values of the length of displacement of the tagged trees recruited to the stream in given sections are presented in Figure 4. In sections A and $\mathrm{B}$, the lengths of the displacement of tagged trees over the study period were small, ranging from 2 to $36 \mathrm{~m}$ (mean $=16 \mathrm{~m}$ ) in the former and from 6 to $32 \mathrm{~m}$ (mean $=19 \mathrm{~m}$ ) in the latter (Figure 4). In section $\mathrm{C}$ they were considerably longer, ranging from 3 to $1003 \mathrm{~m}$ and amounting to $252 \mathrm{~m}$ on average (Figure 4 ).

As a result of the flood in 2010, three trees were displaced relatively short distances in section $\mathrm{C}($ mean $=42 \mathrm{~m}$, maximum $=100 \mathrm{~m})$ and retained in in-channel jams. A definitely larger flood from 2014 was marked only in the lowermost section C, where the wood already occurring in the channel was crushed into smaller pieces and flushed out downstream. The flood of July 2016 was the only major flood in all study sections; during this event 12 trees were displaced, with the mean and maximum lengths of displacement equal $97 \mathrm{~m}$ and $320 \mathrm{~m}$, respectively (Figure 4). In July 2018, a major flood caused by heavy rainfall resulted in considerable bank erosion in the lowest study section. During this event, 41 trees from this section were recruited to the channel and 40 of them were transported (mean displacement $=275$ $\mathrm{m}$, maximum $=1003 \mathrm{~m}$ ). In section $\mathrm{B}$ two previously recruited trees were displaced a mean distance of $32 \mathrm{~m}$, whereas no one tree was delivered to the stream or displaced in section A. The course of this flood thus showed a strongly localised occurrence of the triggering rainfall. A small flood in May 2019 did not displace any tagged trees occurring in the stream.

\subsection{Delivery and displacement of tagged trees in section $A$}

During the study period 21 trees were recruited to the channel in section $A$, with 12 of them delivered as a result of windthrow, 7 by bank erosion, and 2 because of snow overload. Only in this section, riparian trees were recruited to the channel as a result of overloading with snow. Interestingly, here bark beetle infestation did not influence the supply of trees to the channel despite the largest proportion of infested spruce forest along this section. Despite a greater exposure of trees to wind in comparison to the other study sections, trees growing along the banks are strongly attached to the ground and do not easily fall down as their roots are rarely undermined by water. Small stream width causes that fallen riverside trees span the channel without significantly affecting fluvial processes (Figure $5 \mathrm{~A}$ ). However, if their branches reach to the channel bed (Figure $5 \mathrm{~A}$ ),

Table 3 Three-day and the largest one-day precipitation at the Turbacz and Ochotnica Górna stations and the maximum discharge of Mszanka Stream at the Mszana Dolna water-gauge station as indirect information about the five largest flood events on Kamienica Stream during the 2009-2019 monitoring period

\begin{tabular}{|l|l|l|l|l|l|}
\hline Flood & May 2010 & May 2014 & July 2016 & July 2018 & May 2019 \\
\hline Precipitation at the Turbacz station (mm) & $155(91)$ & $4(2)$ & $115(56)$ & $180(95)$ & $67(29)$ \\
\hline Precipitation at the Ochotnica Górna station $(\mathrm{mm})$ & $81(41)$ & $78(54)$ & $76(39)$ & $132(101)$ & $117(68)$ \\
\hline Maximum discharge at the Mszana Dolna station $\left(\mathrm{m}^{3} \mathrm{~s}^{-1}\right)$ & 205 & 170 & 106 & 312 & 135
\end{tabular}



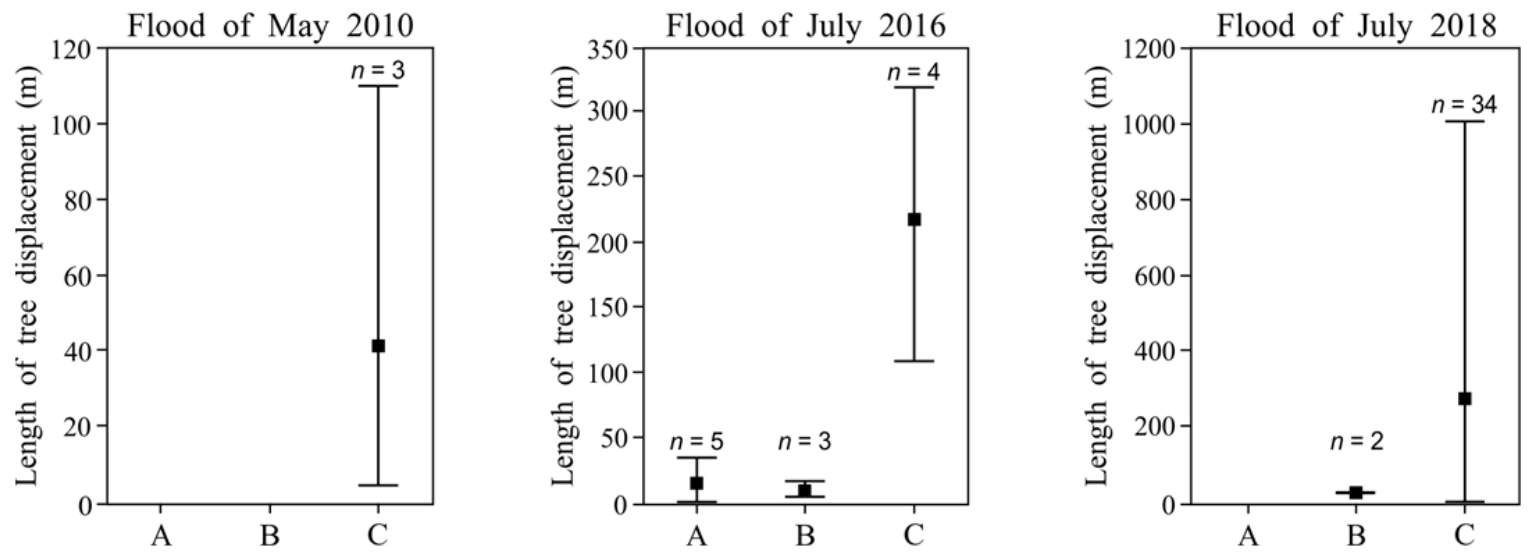

Figure 4 Range and mean length of the displacement during three flood events of tagged trees fallen to the study sections of Kamienica Stream. $n$ denotes the number of tagged trees displaced during a given flood.
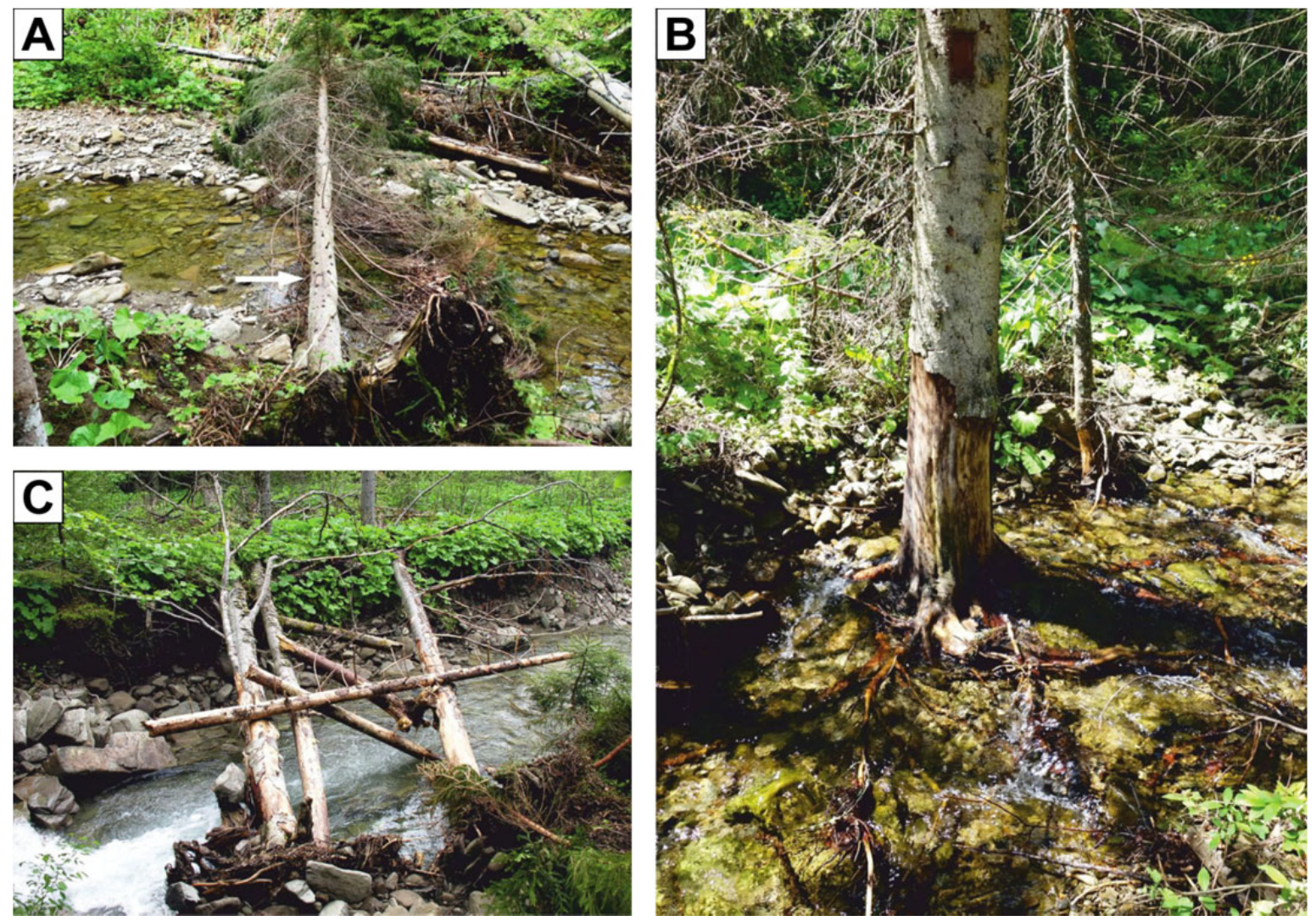

Figure 5 Examples of monitored tagged trees in Kamienica Stream. (A) Fallen spruce tree spanning the channel of Kamienica Stream in section A. The tree was tagged with a numbered aluminium plate (indicated by a white arrow) when growing close to the channel bank. Note tree branches reaching to the channel bed. (B) Dieback of a spruce tree caused by roots waterlogging after the avulsion of a low-flow channel to riparian forest in section A. (C) Three beech trees overturned to the stream by wind in 2010 have continued to span the channel in section C until now. Small logs deposited on the fallen trees by the flood of 2014 indicate a near-bankfull maximum water stage attained by this flood.

they can trap smaller transported wood pieces, which promotes the formation of wood dams and gravel bars upstream of these obstacles.

In the lower part of the section, the stream flowing along the bedrock-alluvial valley slope is fed with boulders and rock blocks, and in the recent past a significant wood supply took place there. During spring 2014, bed aggradation upstream of wood dams located in the lower part of the section caused partial flow avulsion to the riverside forest, where narrow low-flow channels with the slope steeper than that of the main 
channel were formed and showed a tendency towards bed erosion. Living trees suddenly surrounded by water continued to bind alluvium by roots, hence preventing lateral erosion, but waterlogging of roots caused the trees to die quickly, increasing the likelihood of their falling down to the channel during next floods (Figure $5^{\mathrm{B}}$ ). The recruitment of trees to the channel was most dynamic in 2016 as a result of the occurrence of a large flood that was responsible for the delivery of more than half of all trees recruited to this section during 10 years of monitoring.

During the study period mean displacement of the tagged trees delivered to section A equalled 16 $\mathrm{m}$ and the maximum one $36 \mathrm{~m}$. These short transport distances reflected relatively small flood discharges occurring in this section (located in the third-order stream reach) and channel width smaller than the height of riparian trees, facilitating anchoring of fallen trees on both channel banks.

\subsection{Delivery and displacement of tagged trees in section $B$}

In this section, 16 trees (all spruce) were delivered to the channel during 10 years of monitoring (10 as a result of windthrow, 5 by bank erosion, and 1 by landslide). In the lower part of the section, a few windbreaks of the spruce trees infected by bark beetle occurred. This type of wood recruitment is characterised by trees broken at less than $1 / 3$ of their height, with roots still firmly attached to the ground; the broken trees can stand in this position for at least a few years, creating a characteristic landscape of decaying forest.

We also tagged with metal plates 19 trees growing along the margins of an island located in the lower part of the section. At the beginning of the monitoring period, the left bank of this island was adjacent to a dry channel, while the right one to a low-flow channel. Although windthrow of trees infested by bark beetle was a dominant factor of wood recruitment to the channel in the whole section, lateral erosion along the right island bank resulted in undermining and falling to the channel of 5 healthy trees. Since 2016, new wood dams formed by these trees have caused the accumulation of gravel and damming of water, leading to the reactivation of flow in the hitherto dry channel on the left island side. Currently this reactivated channel conveys most of stream flow.

In spring 2012, beavers built a o.8-m-high dam in the upper part of the section, and the dammed water permanently inundated the adjacent, low-lying floodplain. The trees standing in the water died in a few months and fell to the channel, forming complete and active wood dams. The beaver dam was repeatedly damaged by floods and rebuilt just after each flood.

Similar to section A, the transport of fallen tagged trees during floods was very limited, with their mean displacement over the study period amounting to $19 \mathrm{~m}$ and the maximum one to $32 \mathrm{~m}$. Even though the catchment area was here larger than in the highest section, gentler channel slope and greater channel width in this section effectively prevented the entrainment and transport of logs during flood events.

\subsection{Delivery and displacement of tagged trees in section $\mathrm{C}$}

The riparian forest in this section supports the largest trees and is composed of spruce, beech and fir. In this section, 58 trees fell to the channel during the study period as a result of bank erosion (42 trees) and windthrow (16 trees), and their supply was limited to two meteorological and hydrological events. Heavy wind immediately preceding the flood of May 2010 broke 13 spruce trees infected by bark beetle and overturned 3 beeches growing on the channel bank undermined by lateral erosion (Figure $5 \mathrm{C}$ ).

Shortly afterwards, bank erosion during the flood resulted in falling down of 1 tree. A large flood in the summer of 2018 strongly eroded channel banks, delivering 41 trees to the stream. Of this number, we failed to find 6 tagged trees that either had their metal plates buried by sediments and wood accumulations or were transported outside the national park (i.e. the distance of at least $2.7 \mathrm{~km}$ ).

Trees growing along the channel banks in this section are less exposed to wind than in both upstream sections because the stream flows here in a narrow and deep, V-shaped valley. Despite this, wind was an efficient factor of tree delivery to the channel, working together with stream erosion that prepared trees for felling by undermining their 
roots along channel margins. A small flood in 2014 resulted in rapid channel incision (up to $1.2 \mathrm{~m}$ ) in the lower part of the section; this steepened channel margins, making them more susceptible to lateral erosion. Exposing roots of trees growing along channel margins together with the lowering of water surface in the stream after channel incision caused dieback of many riparian trees, that facilitated subsequent erosion of the banks and abundant tree delivery to the channel during the large flood of 2018.

This study section was typified by the largest number of trees recruited to the channel as a result of lateral erosion and by considerably greater mean $(252 \mathrm{~m})$ and maximum (1003 $\mathrm{m}$ ) lengths of the displacement of tagged trees over the study period than the two upstream sections.

\subsection{Location and the degree of decay of wood deposits in stream reaches of different order}

Particular stream reaches differed in the predominant types of wood location in relation to the channel (Figure 6). As trees in the riparian forest grow at various distances from the channel and most of them are taller than channel width, this results in variable configuration of the end of logs in relation to the channel.

In the second-order reach, wood was relatively uniformly distributed among different location

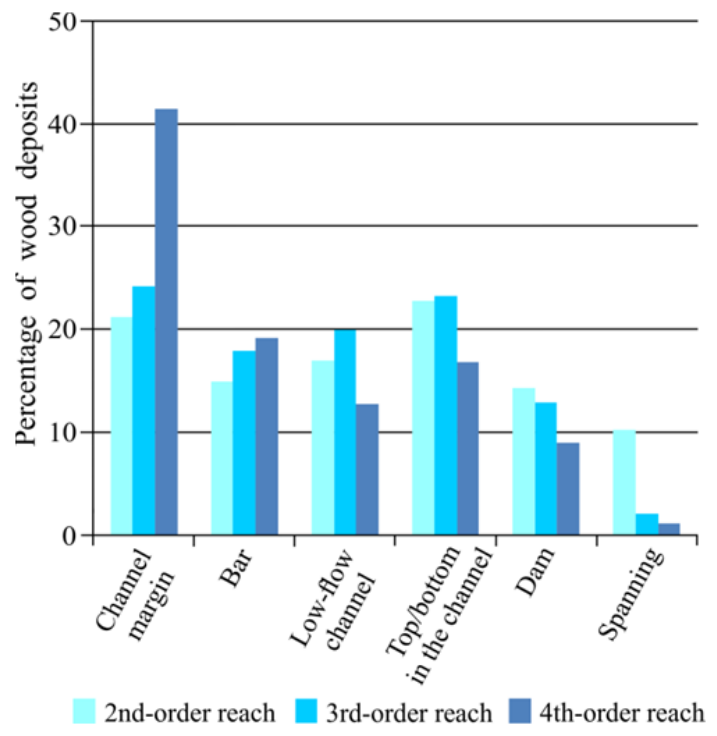

Figure 6 Percentage of large wood deposits occurring in given location types in the second-, third-, and fourth-order reaches of Kamienica Stream. types, with logs with their top or bottom located in the channel being the most abundant (21\% of all wood pieces). This reach was typified by the largest proportion of logs forming wood dams (12\%) and spanning the channel (10\%) among the study reaches (Figure 6), which can be attributed to the relatively large length of wood pieces in relation to channel width. All this indicates a negligible role of transport and redistribution of wood, which was predominantly retained where it fell.

The pattern of wood location in the third-order reach was similar to that recorded in the secondorder reach. It was distinguished by only one feature: a small amount of wood spanning the channel (Figure 6). Moreover, in the lowest part of this reach, the national park service harvested a few died spruce trees standing along a touristic trail and cut them into several small fragments that were stored on a stream bank. These wood pieces of anthropogenic origin will be more susceptible to fluvial transport than most naturally derived large wood, once they are recruited to the stream with the erosion of the channel bank.

In the fourth-order reach, large wood spanning the channel was very scarce because of larger stream width and considerably larger flood discharges. Here, large wood was predominantly retained along channel margins (41\%), on gravel bars (19\%), and with only the top or bottom located in the channel (17\%) (Figure 6). Most of wood pieces were shorter than channel width, as they originated from the breakage of trees into smaller fragments during their fall to the channel or transport by flood flows.

In the second-order reach of Kamienica, $16 \%$ of wood pieces were in a relatively good condition, representing class 1 and 2 of wood decay, whereas a more advanced degree of decomposition, typical of class 3 and 4 , typified $84 \%$ of pieces. In the thirdorder stream reach, this distribution was more even, with $41 \%$ of pieces representing class 1 and 2 of wood decay, and $59 \%$ class 3 and 4 . In the fourth-order reach, classes 1 and 2 constituted 31\% of all wood pieces, and $69 \%$ had typical features of classes 3 and 4 (Figure 7).

\section{Discussion}

The use of metal plates to tag trees growing 


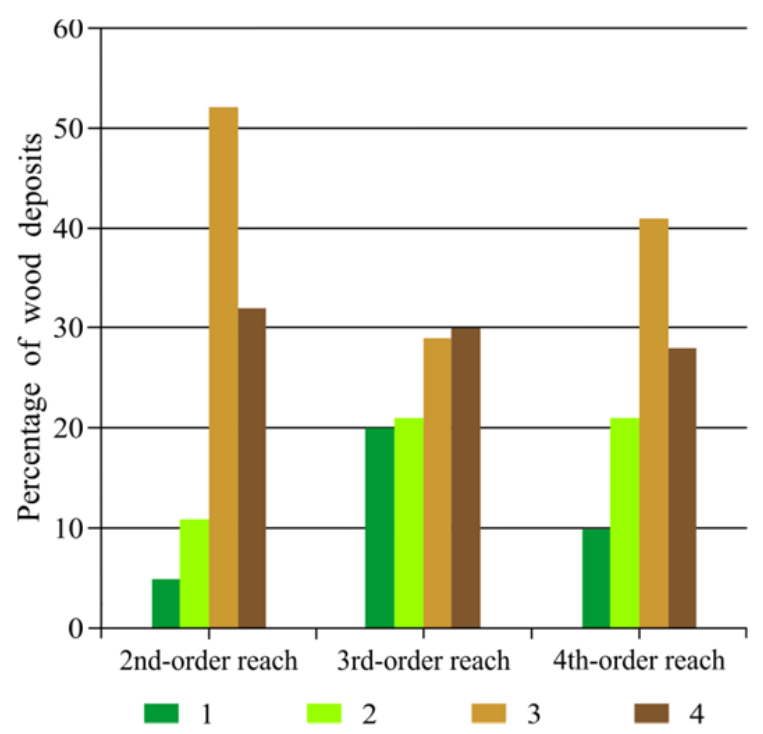

Figure 7 Percentage of large wood deposits in a given class of wood decay recorded in 2012 in the second, third-, and fourth-order reaches of Kamienica Stream. 1 - fresh wood; 2 - loose bark; 3 - no bark, wood hard; 4 - no bark, wood soft.

along Kamienica Stream, combined with the repetitive monitoring of these trees over 10 years, provided valuable information about large wood dynamics in the studied mountain stream. This methodological approach allowed us to identify mechanisms and approximate dates of tree recruitment to the channel and to determine the lengths of displacement of fallen trees during individual floods. The cost of tagging trees with metal plates was low-about two orders of magnitude lower than the cost of tracking wood transport with radio transmitters in another Polish Carpathian watercourse (Mikuś et al. 2016) - and a relatively small amount of time was needed to conduct the monitoring of tagged trees. These advantages of the method allowed us to tag and monitor over 400 trees on a total stream length of $1.35 \mathrm{~km}$. Moreover, metal plates can function as tags for a long time (particularly in comparison to radio transmitters) and are characterized by relatively high efficiency of indicating the location of fallen and displaced trees in a mountain stream. During 10 years of monitoring, we lost only 6 trees, i.e. $1.4 \%$ of the tagged sample and $6.2 \%$ of the tagged trees fallen to the channel. In a few cases, the use of a metal detector was necessary to find trees with invisible or inaccessible plates. The plates were attached to trees with either 5 -cm-long screws (aluminium plates) or 8-cm-long nails (steel and copper plates) and they remain firmly attached to logs even after a few years of their residence in the channel. This means that with the rate of wood decay typical of the moderately cool climate of the Kamienica valley, the threat of plate disconnection from logs is rather low within the time frame of the monitoring period, unless a log is broken just where the plate was attached.

Although bark beetle infestation was not a direct reason for the delivery of spruce trees to the channel, these trees were weakened by beetles, which made them very susceptible to breakage by wind. This type of wood recruitment was typical of the riparian forest with a predominant proportion of spruce, as it is in section B. Dead trees falling perpendicular to the channel often break into several smaller pieces. Such pieces were easily transported by the following flood a distance of several tens of metres and were deposited on larger, more stable wood dams or jams. As these wood accumulations may be destroyed by a major flood, this creates a problem with further monitoring of the $\log$ fragments, of which only one is tagged with a metal plate.

After 7 years of the monitoring of large wood delivery to Kamienica Stream, the turnover period of riparian trees was estimated at 80 years, provided that a similar rate of their delivery persists over a long time (Mikuś et al. 2016). As the riparian area supports trees with ages up to $\sim 160$ years, the estimate of the twice shorter turnover period was interpreted as reflecting increased tree delivery to the stream as a result of bark beetle infestation, which must have accelerated the turnover of the riparian forest (Mikuś et al. 2016). After extension of the monitoring by 3 years, the turnover period of riparian trees can be estimated at 45 years, as $22 \%$ of tagged trees were recruited to the channel during 10 years. This further increase in the rate of turnover of riparian trees was an effect of the occurrence of the large flood of 2018 that recruited to the stream about $10 \%$ of all tagged trees. A combined effect of the operation of both factors accelerating the turnover of riparian trees in the Kamienica valley will be rejuvenation of the riparian forest growing along the stream banks, with a further effect on the dimensions of trees recruited to the channel in the future.

Previous experiments using metal or plastic plates attached to $\operatorname{logs}$ or whole trees already 
resting in the channel or active river zone mostly aimed to determine the distance of transport and the pattern of deposition of large wood (e.g. Haga et al. 2002; Warren and Kraft 2008; Schenk et al. 2014). Similar studies with tagged trees growing along river banks have been conducted very rarely and in slightly different conditions, which makes comparison with their results difficult. Observations in large rivers (e.g. Piégay et al. 1999; Lassettre et al. 2008; Warren et al. 2009) indicated that the dominant process of wood supply is bank erosion during floods. In small mountain streams such as Kamienica in its upper course, the set of processes responsible for wood recruitment to their channels is wider, which is consistent with earlier observations from the Pacific Northwest, USA (Keller and Swanson 1979; McDade et al. 1990; Van Sickle and Gregory 1990).

Despite its advantages, the method used in this study for monitoring the recruitment and transport of large wood has also some limitations. Precise identification of the time of tree delivery to channel requires systematic monitoring after each high-intensity, meteorological or hydrological event. If more than one flood occurred between successive visits of the observer to the stream, it would only be possible to determine the total distance travelled by wood, without its division into individual flood events. Moreover, the effectiveness of this method in tracking a long-distance displacement of tagged trees is limited. Finding trees that were transported far beyond the study section may be time-consuming and not fully successful despite the use of a metal detector, as evidenced by our failure to find 6 trees displaced by the 2018 flood. In particular, trees transported outside the boundary of the national park may be extracted from the channel by local farmers for firewood, which considerably limits the time for their effective search after a flood.

A number of observations indicate negligible mobility of the large wood retained in the secondorder reach of Kamienica Stream: a considerable proportion of logs spanning the channel or forming wood dams, the predominance of perpendicular or near-perpendicular orientation of wood pieces (Mikuś et al. 2016), and the predominance of wood in an advanced state of decay (classes 3 and 4). Notably, a considerable proportion of relatively fresh wood recorded in the stream immediately after a large flood in 1997 (Kaczka 1999) decreased markedly in favour of wood in the advanced state of decay until the inventory in 2012 (Kundzewicz et al. 2017), reflecting the fact that wood pieces delivered to the channel by bank erosion and landslides activated by this flood subsequently have remained in situ and have been subjected to progressive decomposition. This negligible wood mobility can be attributed to small flood discharges occurring in the headwater part of the stream, unable to cause the submergence and flotation of wood pieces, and to small channel width facilitating anchoring of fallen trees on both channel banks (cf. Gurnell et al. 2002). In such headwater stream reaches, debris flows are the only phenomena effectively mobilizing large wood (May and Gresswell 2003; Galia et al. 2018b) due to the high density of the moving fluid, but they are very rare in the flysch part of the Polish Carpathians.

The monitoring of tagged trees indicated very small mobility of trees fallen to the channel in section A (in the third-order stream reach) and section B (in the uppermost part of the fourthorder reach). However, a number of smaller wood pieces generated by the breakage of trees during their fall or decomposition were either reoriented by stream flow or displaced some distance downstream and braced against other, more stable wood pieces (Mikuś et al. 2016). The third-order reach was characterised by a markedly lower proportion of logs spanning the channel than the second-order reach, partly because of larger channel width and partly because of relatively easy breakage of fallen trees killed by bark beetle infestation (Mikuś et al. 2016).

In the monitored section C located ca. $4.5 \mathrm{~km}$ downstream from the beginning of the fourthorder stream reach, mean and maximum lengths of the displacement of fallen tagged trees were several times larger than in sections A and B. The disparity can be partly explained by a strongly localised occurrence of the heavy rainfall causing the major flood of 2018 but mainly reflects a larger channel size and higher flood discharges conveyed in section C. In the fourth-order reach, the prevailing location of logs on channel margins and bars and similar proportions of longitudinal and nearperpendicular orientation of logs indicate that a considerable part of wood pieces were subjected to transport in the stream before their deposition. 
However, as two-thirds of the pieces retained in the reach were in an advanced state of decay, the lengths of their displacement must have been limited, indicating that wood is not readily flushed out to downstream reaches. Major floods tend here to redistribute large wood recruited to the channel and either brace it against stable pieces (hence aggregating wood into jams) or deposit logs along channel margins and on bars, where a relatively small depth of floodwater prevents their flotation (cf. Haga et al. 2002). Therefore, subsequent, smaller floods are unlikely to cause further displacement of the retained wood.

During the few last decades, the amounts of large wood retained in the upper course of Kamienica Stream must have increased because of the cessation of wood removal from the channel since the establishment of the national park in 1980 and accelerated delivery of fallen trees caused by bark beetle infestation of the riparian forest. Insignificant/very low mobility of wood retained in the second- and third-order stream reaches prevents flushing out of the wood to inhabited valley reaches outside the national park even during large floods. Larger mobility of large wood in the fourth-order stream reach causes that a proportion of trees recruited to the channel during a large flood may be flushed out downstream, but most of such trees are retained in the reach, predominantly in higher parts of the active channel, where wood is subsequently subjected to rapid decomposition under subaerial conditions (Harmon et al. 1986). If mobilized by the next large flood, such wood in an advanced state of decay will disintegrate into small fragments and thus will not constitute an important flood hazard to downstream valley reaches.

\section{Conclusions}

Large wood is recruited to the upper course of Kamienica Stream by a few processes, with bank erosion and windthrow having been most effective during 10 years of monitoring. In this period, the effectiveness of strong wind in large wood delivery

\section{References}

Benda LE, Sias JC (2003) A quantitative framework for evaluating the mass balance of in-stream organic debris. to the stream channel must have been increased by the weakening of riparian spruce trees as a result of earlier bark beetle infestation. Large wood was recruited to the channel only during high-intensity meteorological and hydrological events.

Large wood inventory performed in the second- to fourth-order stream reaches and results of the monitoring of fallen tagged trees indicated that the mobility of wood in the stream increases downstream because of increasing flood discharges and the decreasing ability of fallen trees to anchor on the banks of increasingly wide channel. Small and medium floods cannot displace fallen trees longer distances. Even in the fourth-order reach, wood is transported longer distances only during major floods. Here, such floods tend to deposit wood pieces along channel margins and on gravel bars, where wood is subjected to relatively rapid decomposition under subaerial conditions. During a subsequent large flood, most wood pieces already occurring in the channel are thus likely to rapidly disintegrate, rather than being flushed out to downstream, inhabited valley reaches, where they could constitute an important flood hazard.

\section{Acknowledgements}

The study was financed by the statutory funds of the Institute of Nature Conservation, Polish Academy of Sciences, and by the project FLORIST (Flood risk on the northern foothills of the Tatra Mountains; PSPB no 153/2010) supported by a grant from Switzerland through the Swiss Contribution to the Enlarged European Union. We thank two anonymous reviewers for their critical comments on the manuscript.

Open Access This article is distributed under the terms of the Creative Commons Attribution 4.0 International License (http://creativecommons. org/licenses/by/4.o/), which permits unrestricted use, distribution, and reproduction in any medium, provided you give appropriate credit to the original author(s) and the source, provide a link to the Creative Commons license, and indicate if changes were made. 
Faustini JM, Jones JA (2003) Influence of large woody debris on channel morphology and dynamics in steep, boulder-rich mountain streams, western Cascades, Oregon. Geomorphology 51: 187-205. https://doi.org/10.1016/So169-555X(02)0o336-7

Galia T, Ruiz-Villanueva V, Tichavský R, et al. (2018a) Characteristics and abundance of large and small instream wood in a Carpathian mixed-forest headwater basin. Forest Ecology and Management 424: 468-482. https://doi.org/10.1016/j.foreco.2018.05.031

Galia T, Tichavský R, Škarpich V, Šilhán K (2018b) Characteristics of large wood in a headwater channel after an extraordinary event: The roles of transport agents and check dams. Catena 165: 537-550.

https://doi.org/10.1016/j.catena.2018.03.010

Gurnell AM, Piégay H, Swanson FJ, Gregory SV (2002) Large wood and fluvial processes. Freshwater Biology 47: 601-619. https://doi.org/10.1046/j.1365-2427.2002.00916.x

Haga H, Kumagai T, Otsuki K, Ogawa S (2002) Transport and retention of coarse woody debris in mountain streams: An in situ field experiment and a field survey of coarse woody debris distribution. Water Resources Research 38: 11-26. https://doi.org/10.1029/2001WRoo1123

Harmon ME, Franklin JF, Swanson FJ, et al. (1986) Ecology of coarse woody debris in temperate ecosystems. Advances in Ecological Research 15: 133-302.

https://doi.org/10.1016/Soo65-2504(03)34002-4

Kaczka RJ (1999) The role of coarse woody debris in fluvial processes during the flood of the July 1997, Kamienica Łacka Valley, Beskidy Mountains, Poland. Studia Geomorphologica Carpatho-Balcanica 33: 117-130.

Kail J, Hering D, Muhar S, et al. (2007) The use of large wood in stream restoration: experiences from 50 projects in Germany and Austria. Journal of Applied Ecology 44: 1145-1155. https://doi.org/10.1111/j.1365-2664.2007.01401.x

Keller EA, Swanson FJ (1979) Effects of large organic material on channel form and fluvial processes. Earth Surface Processes 4: 361-38o.https://doi.org/10.1002/esp.3290040406

Kramer N, Wohl E (2014) Estimating fluvial wood discharge using time-lapse photography with varying sampling intervals. Earth Surface Processes and Landforms 39: 844-852. https://doi.org/10.1002/esp.3540

Krejčí L, Máčka Z (2012) Anthropogenic controls on large wood input, removal and mobility: examples from rivers in the Czech Republic. Area 44: 226-236.

https://doi.org/10.1111/j.1475-4762.2011.01071.x

Kundzewicz ZW, Stoffel M, Wyżga B, et al. (2017) Changes of flood risk on the northern foothills of the Tatra Mountains. Acta Geophysica 65: 799-807. https://doi.org/10.1007/s11600-017-0075-0

Lassettre NS, Piégay H, Dufour S, Rollet A (2008) Decadal changes in distribution and frequency of wood in a free meandering river, the Ain River, France. Earth Surface Processes and Landforms 33: 1098-1112. https://doi.org/10.1002/esp.1605

Lienkaemper GW, Swanson FJ (1987) Dynamics of large-woody debris in streams in old-growth Douglas-fir forests. Canadian Journal of Forest Research 17: 150-156. https://doi.org/10.1139/x87-027

Lyell C (1837) Principles of geology: being an inquiry how far the former changes of the Earth's surface are referable to causes now in operation. Volume I. James Kay, Jun. \& Brother, Philadelphia.

MacVicar B, Piégay H (2012) Implementation and validation of video monitoring for wood budgeting in a wandering piedmont river, the Ain River (France). Earth Surface Processes and Landforms 37: 1272-1289. https://doi.org/10.1002/esp.3240

May CL, Gresswell RE (2003) Large wood recruitment and redistribution in headwater streams in the southern Oregon Coast Range, U.S.A. Canadian Journal of Forest Research 33:
1352-1362. https://doi.org/ 10.1139/Хo3-023

McDade MH, Swanson FJ, McKee WA, et al. (1990) Source distances from coarse woody debris entering small streams in western Oregon and Washington. Canadian Journal of Forest Research 20: 326-330. https://doi.org/10.1139/x90-047

Mikuś P, Wyżga B, Ruiz-Villanueva V, et al. (2016) Methods to assess large wood dynamics and the associated flood hazard in Polish Carpathian watercourses of different size. In: Kundzewicz ZW, et al. (eds.), Flood Risk in the Upper Vistula Basin. Springer, Cham. pp 77-101. https://doi.org/10.1007/978-3-319-41923-7

Montgomery DR, Collins BD, Buffington JM, Abbe TB (2003) Geomorphic effects of wood in rivers. In Gregory SW, et al. (eds.), Ecology and Management of Wood in World Rivers. American Fisheries Society Symposium 37, Bethesda. pp 2147. ISBN 1-888569-56-5

Niedźwiedź T, Obrębska-Starklowa B (1991) Klimat. In: Dynowska I, Maciejewski M (eds.), Dorzecze górnej Wisły. PWN, Warszawa-Kraków. pp 68-84. ISBN 8-301103-17-5

Piégay H, Thevenet A, Citterio A (1999) Input, storage and distribution of large woody debris along a mountain river continuum, the Drome River, France. Catena 35: 19-39. https://doi.org/10.1016/So341-8162(98)00120-9

Queiros GL, McDermid GJ, Castilla G, et al. (2018) Mapping coarse woody debris with random forest classification of centimetric aerial imagery. Forests 10: 471. https://doi.org/10.3390/f10060471

Ruiz-Villanueva V, Díez-Herrero A, Ballesteros JA, Bodoque JM (2014) Potential large woody debris recruitment due to landslides, bank erosion and floods in mountain basins: A quantitative estimation approach. River Research and Application 30: 81-97. https://doi.org/10.1002/rra.2614

Ruiz-Villanueva V, Bürkli L, Mazzorana B, et al. (2018) Defining and characterizing wood-laden flows in rivers using home videos. In Paquier A, Rivière N (eds.), River Flow 2018 40: 02014.

Schenk ER, Moulin B, Hupp CR, Richter JM (2014) Large wood budget and transport dynamics on a large river using radio telemetry. Earth Surface Processes and Landforms 39: 487498. https://doi.org/10.1002/esp.3463

Van Sickle J, Gregory SV (1990) Modelling inputs of large woody debris to stream from falling trees. Canadian Journal of Forest Research 20: 1593-1601.

Warren DR, Kraft CE (2008) Dynamics of large wood in an eastern U.S. mountain stream. Forest Ecology and Management 256: 808-814.

https://doi.org/10.1016/j.foreco.2008.05.038

Warren DR, Kraft CE, Keeton WS, et al. (2009) Dynamics of wood recruitment in streams of the northeastern US. Forest Ecology and Management 258: 804-813. https://doi.org/10.1016/j.foreco.2009.05.020

Wohl E (2017) Bridging the gaps: An overview of wood across time and space in diverse rivers. Geomorphology 279: 3-26. https://doi.org/10.1016/j.geomorph.2016.04.014

Wohl E, Goode JR (2008) Wood dynamics in headwater streams of the Colorado Rocky Mountains. Water Resources Research 44: Wo9429. https://doi.org/10.1029/2007WRoo6522

Wyżga B, Zawiejska J, Mikuś P, Kaczka RJ (2015) Contrasting patterns of wood storage in mountain watercourses narrower and wider than the height of riparian trees. Geomorphology 228: 275285. https://doi.org/10.1016/j.geomorph.2014.09.014

Wyżga B, Kundzewicz ZW, Ruiz-Villanueva V, Zawiejska J (2016) Flood generation mechanisms and changes in principal drivers. In: Kundzewicz ZW, et al. (eds.), Flood Risk in the Upper Vistula Basin, Springer, Cham, pp. 55-75. https://doi.org/10.1007/978-3-319-41923-7

Wyżga B, Mikuś P, Zawiejska J, et al. (2017) Log transport and deposition in incised, channelized and multithread reaches of a wide mountain river: tracking experiment during a 20-year flood. Geomorphology 279: 98-111. https://doi.org/10.1016/j.geomorph.2016.09.019 